\title{
PERAN ORANG TUA SEBAGAI KELUARGA CYBER SMART DALAM MENGAJARKAN PENDIDIKAN KRISTEN PADA REMAJA GKII EBENHAEZER SENTANI JAYAPURA PAPUA
}

\author{
Elsyana Nelce Wadi $^{1)^{*}}$, Elisabet Selfina ${ }^{2)}$ \\ ${ }^{1)}$ Alumni Prodi Pendidikan Agama Kristen Sekolah Tinggi Theologia Jaffray \\ ${ }^{2)}$ Dosen Prodi Pendidikan Agama Kristen Sekolah Tinggi Theologia Jaffray \\ *) Penulis koresponsdensi:echywady@yahoo.com
}

\begin{abstract}
Abstrak
Tujuan penulisan karya ilmiah ini adalah untuk mengetahui peran orangtua dalam mengajarkan Pendidikan Agama Kristen kepada remaja. Penulisan karya ilmiah ini menggunakan metode kuantitatif dengan teknik pengumpulan data melalui kajian pustaka, penyebaran angket tertutup kepada orang tua dan remaja serta melakukan wawancara terhadap objek kajian. Adapun kesimpulan karya ilmiah ini adalah peran orangtua dalam mengajarkan pendidikan Kristen kepada remaja yaitu mengajarkan firman Tuhan, menjadi pendidik, menjalankan disiplin, menjadi teladan bagi remaja dan menciptakan keluarga cyber smart. Peran orang tua menjadi penentu kehidupan masa remaja anak. Orang tua yang dapat mengerti dan memahami perannya dengan baik akan menuntun remaja kepada jalan yang benar seperti yang dikehendaki oleh Tuhan sebaliknya, orang tua yang tidak memahami perannya dengan baik di dalam keluarga akan kehilangan anak remajanya di era globalisasi ini.

Kata-kata kunci: peran, orang tua, Pendidikan Kristen, remaja, globalisasi.

The purpose of the writing of this scientific work is to understand the role of parents in teaching Christian Education to youth. The writing of this work used a quantitative method with the technique of gathering data through literature study, the handing out of closed questionnaires to parents and youth, along with conducting interviews with the subjects of the study. In addition, the summary of this scientific study of the role of parents in teaching Christian Education to youth, is that parents teach the word of God, become the educators, carry out discipline, become examples to their teenagers, and create a cyber smart family. The role of the parents becomes a determinant for the lives of their youths. Parents that can understand and grasp their role well will guide their youth to walk on the right road in accordance with the will of God. On the other hand, parents that do not understand well their role in the family will lose their youth in this era of globalization.
\end{abstract}

Keywords: role, parents, Christian Education, youth, globalization. 


\section{Pendahuluan}

Remaja adalah kelompok usia 10-20 tahun yang sedang mengalami perkembangan secara fisik, emosi, sosial, mental dan kerohanian. Usiausia ini merupakan masa yang sangat rentan terhadap segala perubahan yang terjadi, ini terjadi karena anak-anak usia ini masih mengalami krisis identitas, di mana kelompok usia ini masih berjuang dengan kemampuan diri sendiri demi memahami tentang identitas dan tujuan keberadaan hidupnya secara keseluruhan, terutama dengan banyak hal yang sedang terjadi di masa-masa modern ini, termasuk pengaruh globalisasi dunia.

Oleh karena itu, remaja membutuhkan pertumbuhan rohani tidak hanya ketika mengikuti ibadah saja tetapi setiap hari bahkan setiap saat terutama bila berdampak pada perilaku mereka. ${ }^{l}$ Untuk mencegah agar remaja tidak terpengaruh oleh kemajuan negatif yang sedang terjadi, maka tantangan dalam mendidik remaja untuk menghadapi kemajuan teknologi menjadi tugas wajib orang tua mengajar pendidikan Kristen guna membina moral dan kerohanian anak karena keluarga merupakan lembaga pertama yang dijadikan oleh Tuhan dengan tujuan yang mulia.

Salah satu fenomena globalisasi yang terjadi adalah mulai merambaknya penggunaan handphone dan internet. Internet dan era globalisasi sangat erat hubungannya, karena dengan internet semua individu dapat mendunia atau masuk ke era globalisasi. Proses perubahan ini membawa dampak yang sangat terasa bagi anak remaja di dunia secara khusus anak remaja di GKII Ebenhaezer Sentani tempat penelitian penulis.

Penggunaan teknologi komunikasi memiliki banyak hasil yang positif bagi kaum muda. Hal itu dapat meningkatkan perkembangan intelektual dan sosial dan bisa memberikan banyak kesempatan dan keuntungan pendidikan. $^{2}$ Sebagai contoh penggunaan internet, esensinya merupakan sarana penyampaian informasi. Tujuan proses pendidikan untuk menyebarluaskan ilmu pengetahuan dan menyampaikan informasi. ${ }^{3}$ Tentunya globalisasi memiliki peluang positif

1 Jonathan Matheus dan Elisabet Selfina, "Peran Pembina Remaja Bagi Perkembangan Perilaku Remaja Di GKII Tanjung Selor Kalimantan Utara," Jurnal Jaffray 13, No. 1 (April 2014):18.

${ }^{2}$ Griffith Institute for Educational Research, "The ACMA Cybersmart Outreach Program Evaluation Qualitative Report," diakses 10 Dember 2015, http://www.cyber smart.gov.au/About\%20Cybersmart/Research//media/Cybersmart/About\%20Cybersm art/Documents/The\%20ACMA\%20Cybersmart\%200utreach\%20Program\%20Evaluati on\%20Qualitative\%20Report\%20October\%202011\%20Griffith\%20University.PDF.

3 Miklos A. Vasarhelyi and Lynford Graham, "Cybersmart: The Future of Education in the Age of the Internet," diakses 10 Desember 2015, http://raw.rutgers.edu/ MiklosVasarhelyi/Resume\%20Articles/PROFESSIONAL\%20PAPERS/P17.\%20cybersm art $\% 20$ education $\% 20$ and $\% 20$ the $\% 20$ internet.pdf 
bagi remaja untuk mengembangkan potensi diri dan memperluas pemahaman tentang dunia dan ilmu pengetahuan, mencetus ide dan gagasan yang baru dan ikut terlibat dalam perkembangan dunia.

Di balik semua fakta positif ini terdapat banyak hal negatif yang terjadi dan telah memengaruhi anak remaja di tempat penelitian penulis dikarenakan perkembangan global ini, seperti banyak informasi yang tidak tersaring dan diterima begitu saja oleh anak-anak remaja yang menyebabkan perubahan dalam tingkah laku dan pola pikir yang negatif. Remaja mulai menutup diri dan membangun pagar-pagar pribadi di sekitar hidupnya, dan mulai merasa nyaman dengan dunia dan dirinya sendiri. Kelompok ini mulai egois, tidak memikirkan orang lain dan karena semua informasi yang dibutuhkan dapat ditemukan dengan mudah. Dari segi cara pandang, zaman ini telah melihat kehebatan teknologi informasi dan pengetahuan sebagai "dewa" yang mampu membuat hidup manusia menjadi lebih baik dan indah - manusia memuja teknologi sebagai hasil karyanya dan mengesampingkan Tuhan yang meletakkan pengetahuan. ${ }^{4}$

Firman Tuhan digeserkan oleh teknologi dan pengetahuan yang menyebabkan manusia dan terlebih khusus anak remaja kehilangan dasar yang menjadi penuntun hidup, hal ini membawa dampak yang buruk bagi perilaku, kerohanian, sosial dan karakter anak remaja di daerah tempat penelitian penulis. Semua ini terjadi karena keluarga secara khusus orang tua tidak menjalankan PAK dengan serius di dalam keluarga.

\section{Peran Orang Tua Dalam Keluarga}

Mengenali anak-anak dari sisi generasi mereka adalah memahami campuran dari berbagai hal dalam diri dan lingkungan hidupnya. Di antaranya: nilai-nilai yang disanjung, bagaimana mereka menyikapi hidup, kebiasaan dan perilakunya, medianya, teman sebaya, serta bahasanya. Kesemuanya ini bergabung membentuk cara pandang ataupun wawasan yang pada gilirannya mengarahkan hidup mereka. ${ }^{5}$

Setiap orang tua yang ingin memahami dan mendidik anak remaja, haruslah memahami dunia remaja. Orang tua tidak dapat menutup diri dan menarik diri dari kenyataan yang sedang terjadi bahwa secara tidak langsung juga telah terlibat di dalam pengaruh era globalisasi. Ada banyak reaksi orang tua dalam menyikapi tantangan globalisasi ini khususnya perkembangan dalam dunia teknologi; dari orang tua yang

\footnotetext{
4 "Suara Kenabian Tentang Anak dan Pemuda di Tengah Krisis," Buletin BPC Perkantas Edisi Agustus, 2009, 64.

5 Hellen Chou Pratama, Cyber Smart Parenting (Bandung: Visi Anugerah Indah, 2012), 37-38.
} 
sangat ketakutan, tidak peduli, hingga yang sangat terbuka terhadap perkembangan ini. "Reaksi-reaksi tersebut dikategorikan menjadi tiga, yaitu; menarik diri (Bubble Way), Menyerahkan diri (EGP - Emang Gue Pikirin) dan menerima dengan kritis (Smart Way)."

Yang diharapkan dari tiap orang tua yaitu reaksi di mana orang tua dapat menerima dengan kritis. Yang dimaksud dengan menerima dengan kritis yaitu orang tua tidak hanya menerima perkembangan era digital ini dengan mentah, namun dengan tegas dapat menilainya berdasarkan pandangan Alkitab.

Prinsip-prinsip dalam Alkitab menjadi dasar yang kuat bagi setiap keluarga dalam mengajarkan pendidikan Kristen kepada anak-anak remaja.

\section{Mengajar dengan Membicarakannya}

Ulangan 11:19 "Kamu harus mengajarkannya kepada anak-anakmu dengan membicarakannya, apabila engkau duduk di rumahmu dan apabila engkau sedang dalam perjalanan, apabila engkau berbaring dan apabila engkau bangun;"

Orang tua bertanggung jawab membicarakan firman Tuhan kepada remaja dan berusaha untuk menuntun setiap remaja kepada hubungan yang setia dengan Tuhan. Tujuan dari membicarakan firman Tuhan kepada remaja ialah mengajar remaja untuk takut akan Tuhan, berjalan pada jalan-Nya, mengasihi dan menghargai Dia serta melayani Dia dengan sepenuh hati dan jiwa (Ul. 4:6).

Dalam membicarakan firman Tuhan kepada remaja membutuhkan waktu yang baik dan tepat, namun untuk mendapatkan waktu dari remaja di generasi ini sangat susah karena keseharian anak remaja akan dipenuhi dengan alat-alat digital berupa handphone, gadget, Notebook, Smartphone, dan lainnya. Selain itu, anak remaja juga akan banyak menghabiskan waktu bersama dengan teman-teman sebayanya di luar rumah. Oleh karena itu, firman Tuhan di dalam Ulangan mengatakan bahwa membicarakan firman Tuhan kepada anak-anak bukan hanya ketika sedang berada di dalam rumah saja melainkan pada waktu bangun pagi, pada waktu bersama di luar rumah dan bahkan pada waktu akan tidur di malam hari.

\section{Menjadi Pendidik}

Mendidik remaja bukanlah suatu hal yang rumit, tetapi didiklah remaja dengan benar berdasarkan dengan pengajaran firman Tuhan. Amsal 29:14, "Raja yang menghakimi orang lemah dengan adil, tahtanya tetap kokoh untuk selama-lamanya." Amsal 21:3, "Melakukan kebenaran

\footnotetext{
${ }^{6}$ Hellen Chou Pratama, Cyber Smart Parenting, 25.
} 
dan keadilan lebih dikenan Tuhan dari pada korban". Orang tua mendidik remaja dengan adil, dengan ajaran kebenaran yang berdasarkan firman Tuhan, maka keluarga akan kokoh.

Mendidik remaja merupakan suatu tugas yang besar dalam menuntun remaja memiliki potensi yang bermanfaat bagi generasi ini, jika orang tua remaja tidak dengan sadar mendidik remaja kepada nilainilai yang baik, maka dapat mengakibatkan masalah yang sangat besar. Adalah sangat mendasar bagi orang tua untuk membicarakan, membahas dan menumbuh kembangkan nilai dalam diri remaja generasi ini berdasarkan firman Tuhan. "Setiap orang tua perlu mengklarifikasi dan mengajarkan nilai-nilai luhur keimanan ataupun moralitas kepada anakanaknya serta mengkondusifkan proses interialisasinya (proses diterima dan tertanamnya nilai dalam diri seorang anak)."

Sebagai pendidik dalam keluarga ada beberapa hal yang dapat dilakukan oleh orang tua dalam hal mendidik anaknya yaitu: ${ }^{8}$

- Membentuk rutinitas sehari-hari keluarga dengan menyediakan waktu dan tempat yang cukup untuk belajar dengan anak-anak dan menugaskan tanggung jawab untuk tugas-tugas di dalam keluarga.

- Memantau kegiatan di luar sekolah, misalnya menetapkan batasan menonton televisi, mengurangi waktu bermain, dan memantau temantemannya yang bergaul dengan anaknya.

- Orang tua harus menciptakan lingkungan rumah yang mempromosikan pembelajaran, memperkuat apa yang diajarkan di sekolah dan mengembangkan keterampilan hidup. Anak-anak perlu menjadi orang dewasa yang bertanggung jawab.

Selain itu orang tua juga bertanggung jawab untuk menjaga anaknya bebas dari kekerasan fisik, seksual, dan emosional, menjaga benda-benda yang tidak aman supaya terkunci atau di luar jangkauan dari anaknya yang benar potensi bahaya di sekitar rumah. Secara moral dan rohani, orang tua mendidik anak-anak tentang nilai-nilai kualitas hidup berikut: kejujuran, hormat, tanggung jawab, belas kasihan, kesabaran, pengampunan, murah hati dan lain-lain. ${ }^{9}$

Orang tua dapat mendiskusikan banyak hal bersama dari hal-hal keseharian seperti pengelolaan waktu, gaya hidup dan konsumerisme, hingga topik yang sulit, antara lain: seks dan pornografi, homoseksual dan lesbianisme, predator dunia maya, games kekerasan, serta penipuan

\footnotetext{
${ }^{7}$ Pratama, 102.

${ }^{8}$ Adewumi Moradeke Grace, Olojo oludare Jethro, Falemu Funke Aina, "Roles Of Parent On The Academic Performance Of Pupils In Elementary Schools," International Journal of Academic Research in Business and Social Sciences 2, No. 1 (January, 2012): 197.

${ }^{9}$ Adewumi Moradeke Grace, Olojo oludare Jethro, Falemu Funke Aina, "Roles Of Parent On The Academic Performance Of Pupils In Elementary Schools," International Journal of Academic Research in Business and Social Sciences 2, No. 1 (January, 2012): 198.
} 
di dunia maya. Semuanya ini harus dibicarakan secara terbuka dan dari berbagai sudut pandang kemudian membandingkannya dengan sudut pandang Alkitab.

\section{Disiplin}

Pengajaran dari orang tua terhadap anak-anak dalam Perjanjian lama menurut kitab Amsal adalah "kedisiplinan" - Amsal 3:11-12; 19:15; 22:15. Kitab Amsal memberi penekanan yang sangat besar pada disiplin dan benar-benar menaruh perhatian sehingga disiplin dijalankan bersamaan dengan hukuman di dalamnya. Disiplin berarti harus meneladani apa yang Tuhan ajarkan berdasarkan hukum Taurat dan apabila anak lalai melakukannya maka akan diberlakukan hukuman, namun hukuman ini berjalan bukan berdasarkan kemarahan melainkan berdasarkan kasih (Ams. 3:11-12).

Disiplin berbicara mengenai banyak hal yang dapat dilakukan oleh orang tua kepada anak remaja yang berhubungan dengan alat komunikasi, media dan teknologi informasi yang digunakan. Berikut ada beberapa langkah dalam mendisiplinkan anak remaja yang dapat dilakukan, yaitu: ${ }^{10}$

Tetapkan batas/aturan, setiap orang tua bertanggung jawab untuk memberikan batasan/aturan kepada remaja dalam beraktifitas dengan gadget. "Aturan atau batas adalah sebuah pagar perlindungan yang akan memberikan rasa aman bereksplorasi kepada setiap anak di masa pertumbuhannya." Orang tua harus dengan tegas memberikan batasan atau aturan kepada remaja dalam penggunaan internet dan alat komunikasi. Misalnya; remaja diijinkan untuk bermain dengan gadget atau internet hanya setelah selesai mengerjakan tugas rumahnya, dalam menonton televisi juga dibatasi hanya beberapa jam dalam sehari.

Pengawasan, orang tua sangat diharapkan untuk dapat mengawasi remaja dalam menggunakan internet dan gadgetnya. Ada baiknya jika orang tua memasang filter pada situs-situs tertentu yang kurang baik untuk ditonton pada notebook dan sebaiknya orang tua juga harus dapat melihat isi dari gadget anak remajanya.

Berdasarkan penelitian seperti yang dikutip oleh Tapskott,

Beberapa survei yang dilakukan pada tahun 2002 di Amerika melaporkan bahwa $41 \%$ lebih anak remaja usia 18 tahun mengakui bahwa orang tua mereka tidak mengetahui apa yang dilakukannya ketika sedang online, dan survei lain pada tahun 2006 melaporkan bahwa 38\% anak SMA kadang menyembunyikan aktivitas online mereka dari orang tuanya. ${ }^{11}$

10 Bandingkan Hellen Chou Pratama, Cyber Smart Parenting (Bandung: Visi Anugerah Indonesia, 2012), 87.

${ }^{11}$ Pratama,100. 
Situasi ini mendatangkan tantangan yang besar bagi orang tua yang telah berubah dari pembentukan nilai-nilai yang ada di dalam keluarga menuju pembentukan yang ditawarkan oleh dunia melalui gadget digital.

\section{Mengajar Melalui Keteladanan}

Pengajaran yang terdapat dalam kitab Amsal ini bersifat verbal, terdengar ayat-ayat yang menyatakan secara langsung "Hai anakku". Tercermin dalam kitab Amsal bahwa semua yang di ajarkan itu merupakan suatu "keteladanan" - 20:7; 23:26; 13:20, penting untuk orang tua menjadi teladan bagi anak-anak. Meneladani bukanlah sesuatu yang diajarkan kepada anak, namun sikap meneladani sudah ada pada diri anak ketika dilahirkan.

Menjadi teladan yang baik dalam sebuah keluarga merupakan suatu komitmen yang harus diterapkan dari orang tua. Dalam 2 Timotius 1:5 "Sebab aku teringat akan imanmu yang tulus ikhlas, yaitu iman yang pertama-tama hidup di dalam nenekmu lois dan di dalam ibumu Eunike dan yang aku yakini hidup juga di dalammu." Ayat ini membuktikan bahwa keteladanan iman dari orang tua sangat memengaruhi masa muda Timotius.

Ada sebuah pernyataan mengatakan, "strong parents, strong children" dan juga sama maknanya dengan suatu pernyataan, like father, like son. Dua pernyataan ini sadar atau tidak sadar dilakukan oleh orang tua sehingga sikap yang positif terlihat dari kaca mata anak dan akan memberikan pengaruh sampai kepada keturunan anak-cucu." ${ }^{\prime 2}$ Howard Hendrik mengatakan dalam bukunya, "Bahwa Anda tidak dapat memberikan apa yang Anda tidak ketahui. Anda tidak mengajarkan kepada anak Anda apa yang belum Anda ketahui sebelum seorang ayah atau ibu dapat membina keinginan anaknya terhadap hal-hal rohani, terlebih dahulu ia sendiri harus mempunyai pengalaman rohani dengan Kristus."13

Dalam menggunakan internet dan alat digital lainnya juga orang tua harusnya memberikan teladan yang baik. Orang tua tidak dapat mendidik dalam pengaturan waktu, pengawasan terhadap penggunaan internet dan alat digital apabila orang tua sendiri tidak dapat mendisiplinkan diri sendiri dalam penggunaannya. Baik untuk orang tua ikut terlibat di dalam dunia anak remajanya, namun bukan untuk terbawa kenikmatan teknologi tetapi untuk dapat melihat, mengamati,

12 Catatan Ann Grinnell, Pembacaan Wajib PAK Remaja-Pemuda (Makassar: STT Jaffray, 2012), 130 .

${ }^{13}$ Howard Hendriks, Membina Temperamen Anda (Bandung: Kalam Hidup, 1982), 178. 
mengawasi dan memberikan keteladanan yang baik buat anak remajanya.

\section{Menjadi Keluarga Cyber Smart}

Firman Tuhan menyingkapkan prinsip bahwa untuk menyesuaikan diri dengan perubahan, orang tua perlu berubah secara cerdas. Tuhan adalah Allah yang dinamis, Dia bekerja dengan cara yang ajaib dan terus melakukan karya pemeliharaan-Nya secara kreatif dan inovatif. Untuk mengajar remaja generasi $Z$, orang orang tua dituntut untuk berubah. Generasi $Z$ menuntut orang tua untuk berubah dan menyesuaikan strategi pengajaran dengan tantangan dan kebutuhan remaja generasi $Z$. Salah satu strategi yaitu, menjadi keluarga Cyber Smart. Menjadi keluarga Cyber Smart adalah keluarga yang mampu memetik berbagai keuntungan dan manfaat dari kemajuan teknologi dan meminimalisasikan efek negatif yang mengikutinya. ${ }^{14}$ Orang tua tidak dapat menarik anak remajanya untuk menjauhi perkembangan teknologi, tetapi orang tua harus ikut serta dalam dunia remaja. Orang tua harus mendampingi dan mampu untuk memilah setiap informasi yang diperoleh dan membimbing anak remaja dalam mengikuti perkembangan yang terjadi.

\section{Studi Penelitian}

Studi penelitian ini untuk mengetahui pengaruh peran orang tua dalam mengajarkan pendidikan Kristen pada remaja GKII Ebenhaezer Sentani Jayapura Papua.

\section{Responsden}

Berdasarkan hasil wawancara yang dilakukan dengan pembina remaja GKII Ebenhaezer mempunyai jumlah keseluruhan remaja adalah 43 orang dengan 4 orang adalah simpatisan, 9 orang adalah tunas remaja dan 30 orang adalah remaja." 15 Oleh karena itu, angket hanya diberikan kepada 30 orang remaja. Jumlah angket yang diberikan kepada orang tua adalah 25 lembar karena terdapat 3 orang anak remaja yang mempunyai 1 orang tua.

\section{Hasil Penelitian}

Tanggung Jawab Orang Tua Dalam Mengajarkan Pendidikan Kristen

Responden remaja memberikan penilaian tentang tanggung jawab orang tua dalam mengajarkan pendidikan Kristen dalam keluarga dengan membicarakannya sesuai dengan firman Tuhan menghasilkan

\footnotetext{
${ }^{14}$ Pratama, 89.

${ }^{15}$ Anna Ajamiseba, Wawancara Oleh Penulis, Sentani, 27 Mei 2015.
} 
pernyataan bertanggung jawab $(63,4 \%)$; kadang-kadang bertanggung jawab (33,3\%); dan orang tua yang tidak bertanggung jawab $(3,3 \%)$ Berdasarkan hal tersebut dinyatakan bahwa remaja GKII Ebenhaezer menjawab sebagian besar orang tua mereka telah mengajarkan firman Tuhan di dalam keluarga.

Namun, masih dalam pembahasan yang sama yaitu mengajar dengan membicarakan. Remaja mengakui bahwa komunikasi pendidikan Kristen dalam keluarga hanya terjadi dalam satu arah saja karena tidak terjadi saling komunikasi di dalamnya. Remaja mengakui menerima pengajaran pendidikan Kristen hanya terjadi kadang-kadang (63.4\%); remaja yang menerima setiap hari pengajaran pendidikan Kristen $(33.3 \%)$; dan sisanya tidak mendapatkan pengajaran pendidikan Kristen $(3.3 \%)$.

Hasil responden orang tua remaja mengatakan sudah bertanggung jawab dalam mengajarkan firman Tuhan (88\%); kadang-kadang mengajarkan (12\%). Hasil ini menunjukkan orang tua telah memahami peranannya di dalam keluarga untuk mengajarkan anak remajanya firman Tuhan, namun bila dibandingkan hasil jawab remaja tampak perbedaan karena ada 3,3\% remaja tidak menyadari adanya tanggung jawab orang tuanya terhadap mereka dalam hal pengajaran pendidikan Kristen. Sebanyak 68\% orang tua mengatakan bahwa telah berusaha untuk mendiskusikan firman Tuhan bersama-sama dengan remaja, dan sisanya 32\% mengatakan kadang-kadang.

Hasil wawancara kepada orang tua dan remaja juga membenarkan hasil di atas. Salah satu orang tua yang diwawancarai mengatakan bahwa telah mengajarkan firman Tuhan kepada remaja dan seluruh anggota keluarganya di dalam keluarga. Namun, komunikasi satu arah antara remaja dan orang tua menyebabkan rata-rata remaja hanya mendengarkan tanpa memberikan responss dan juga ada remaja yang memberikan respons secara berlebihan atas teguran atau nasihat yang diberikan oleh orang tua. ${ }^{16}$ Dan menurut salah seorang remaja yang diwawancarai mengatakan bahwa seringkali orang tua mengajar atau menegur, memberikan nasihat pada remaja dengan emosional atau pendekatan yang tidak tepat sehingga remaja tidak memberikan respons yang baik. ${ }^{17}$

Firman Tuhan tidak hanya untuk diajarkan kepada remaja, akan tetapi orang tua juga harus menolong remaja untuk melakukan firman Tuhan. Pendekatan persahabatan dan kasih Kristus dapat memengaruhi respons yang akan terjadi. Nasihat orang tua harus bijaksana dalam menasihati dan memberikan pengajaran kepada remaja sehingga

\footnotetext{
${ }^{16}$ Yosepina Cawem, Wawancara Oleh Penulis, Sentani, 21 Mei 2015.

${ }^{17}$ Yohana Talahala, Wawancara Oleh Penulis, Sentani, 23 Mei 2015.
} 
pengajaran itu dapat diterima baik oleh remaja dan dilakukan dalam pertumbuhan rohaninya.

\section{Peran Orang Tua Sebagai Pendidik}

Peran orang tua sebagai pendidik bagi remaja dalam hal ini memberi didikan firman Tuhan tentang penggunaan internet/gadget. Penggunaan internet memiliki dampak negatif dan positif. Responden remaja mengatakan bahwa orang tua mereka mendidik dengan nasihat firman Tuhan untuk penggunaan internet atau teknologi informasi (20\%); kadang-kadang (23.4\%); dan lebih banyak orang tua mengabaikan remajanya (56.6\%). Remaja menyatakan bahwa orang tua mengajarkan nilai-nilai yang baik dalam mendidik (90\%); kadang-kadang (10\%).

Orang tua menjalankan perannya sebagai pendidik dalam keluarga secara khusus bagi remaja dalam penggunaan internet/gadget. Responden orang tua melakukan perannya sebagai pendidik (40\%); kadang-kadang (32\%); dan orang tua yang tidak melakukan tugasnya sebagai pendidik (28\%). Orang tua selalu menanamkan nilai-nilai baik dari apa yang mereka ajarkan (100\%), sekali pun sumber informasi itu tidak berasal dari internet. Berdasarkan wawancara penulis dengan seorang remaja mengatakan bahwa orang tua mengajarkan firman Tuhan namun, sumber informasinya tidak diperoleh dari internet. ${ }^{18}$ Maksudnya adalah begitu banyak informasi liar di internet dan media sosial yang mudah mengecohkan iman remaja. Oleh karena itu, orang tua berperang penting mengajarkan teladan Yesus pada remaja supaya dunia informasi internet tidak mampu memengaruhi iman mereka.

Orang tua belum optimal menjalankan perannya untuk menjadi seorang pendidik bagi remaja di era globalisasi yaitu pengajaran yang disesuaikan dengan perkembangan dunia remaja tersebut. Sedangkan berdasarkan wawancara kepada seorang orang tua mengatakan bahwa telah mendiskusikan informasi atau nilai-nilai yang diperoleh dari internet bersama dengan remaja. ${ }^{19}$ Orang tua harus lebih memahami dan menjalankan perannya sebagai pendidik bagi remaja yang disesuaikan dengan dunia remaja karena didikan dari orang tua berdasarkan firman Tuhan akan mampu menuntun remaja di era globalisasi ini.

Hasil penelitian tersebut di atas menunjukkan bahwa orang tua belum optimal memahami pengaruh informasi internet terhadap perkembangan anaknya. Selain itu, orang tua tampaknya tidak menggunakan informasi via internet untuk didiskusikan dengan anakanaknya, walaupun $90 \%$ orang tua mengajarkan nilai-nilai baik, tetapi sepertinya bersumber di luar internet.

\footnotetext{
${ }^{18}$ Ibid.

${ }^{19}$ Dorlince, Wawancara Oleh Penulis, Sentani, 21 Mei 2015.
} 


\section{Disiplin Terhadap Penggunaan Gadget dan Internet}

Berdasarkan data yang dihasilkan bahwa remaja mengatakan bahwa orang tua menerapkan disiplin dalam keluarga seperti waktu bermain dan waktu dalam penggunaan gadget/internet (43.4\%); kadang-kadang (46.6\%) dan orang tua yang tidak menerapkan hanya 10\%. Responden remaja menyatakan bahwa orang tua mereka memberikan aturan dalam penggunaan gadget dan internet (40\%); kadang-kadang (33.4\%); dan $26.6 \%$ yang mengatakan tidak diberikan aturan oleh orang tua mereka. Pertanyaan berikut dijawab oleh responden remaja bahwa mereka diawasi oleh orang tua dalam penggunaan gadget (23.4\%); kadangkadang (10\%); dan 66.6\% remaja mengatakan tidak diawasi oleh orang tuanya.

Pendapat orang tua mengatakan bahwa telah menjalankan disiplin dalam waktu bermain, dan waktu penggunaan gadget dan internet (72\%); kadang-kadang (24\%); dan 4\% mengatakan tidak melakukannya. Orang tua menjawab bahwa telah memberikan aturan tentang penggunaan gadget (60\%); kadang-kadang (24\%); dan 16\% orang tua mengatakan tidak memberikan aturan. Sedangkan orang tua yang telah mengawasi penggunaan gadget pada anak remajanya (68\%); kadangkadang (12\%); dan 20\% mengatakan tidak mengawasinya. Wawancara penulis dengan beberapa anak remaja mengatakan bahwa orang tua tidak memberikan aturan/batasan, mendisiplinkan terlebih mengawasi remaja tersebut dalam menggunakan gadget/internet. Orang tua bahkan tidak mengetahui apa yang sedang dilakukan pada saat remaja sedang bermain dengan gadget/internet. ${ }^{20}$

Berdasarkan hasil di atas dapat disimpulkan bahwa sekalipun orang tua mengatakan bahwa telah menjalankan disiplin bagi remaja dalam penggunaan internet dan gadget namun, bagi remaja sendiri masih merasakan kebebasan tanpa ada batasan, aturan atau pengawasan dari oang tua. Hal ini berarti bahwa tanggung jawab orang tua belum optimal dalam mengarahkan, menasihati anak remajanya menerapkan disiplin dalam penggunaan alat-alat digital. Di samping itu, orang tua belum memahami tujuan disiplin terhadap penggunaan gadget dan internet.

\section{Orang Tua Mengajar Melalui Keteladanan}

Responden remaja mengatakan bahwa orang tua telah menjadi teladan yang baik dalam penggunaan pertumbuhan iman rohani dan dalam penggunaan gadget (63.3\%); kadang-kadang (13.3\%); dan $23.4 \%$ mengatakan tidak mengajarkannya. Orang tua mengatakan bahwa telah menjadi teladan yang baik dalam pertumbuhan iman rohani remaja dan dalam penggunaan gadget (80\%); kadang-kadang $12 \%$ dan $8 \%$ dengan

\footnotetext{
${ }^{20}$ Wawancara Oleh Penulis kepada beberapa remaja. Sentani, 23 Mei 2015.
} 
jujur berkata tidak. Wawancara penulis dengan beberapa remaja mengatakan bahwa orang tua telah mengajarkan dan memberikan teladan yang baik dalam kehidupan rohani dan dalam penggunaan gadget. ${ }^{21}$ Wawancara dengan orang tua juga memberikan komentar yang sama yaitu bahwa orang tua telah berusaha untuk memberikan teladan yang baik bagi remaja. ${ }^{22}$

Hasil ini dapat disimpulkan bahwa orang tua di GKII Ebenhaezer telah menjadi teladan yang baik bagi remaja, namun perlu berulangulang orang tua mengajarkan kepada anak remaja tentang firman Tuhan, batasan dan awasan dalam menggunakan gadget dan internet.

\section{Orang Tua Menjadi Keluarga Cyber Smart}

Orang tua mempunyai hubungan komunikasi yang baik dengan remaja. Responden remaja mengatakan mempunyai waktu untuk bersama dengan orang tua (56.6\%); kadang-kadang (20\%); dan 23.4\% mengatakan tidak. Responden remaja mengatakan orang tua mereka memberi arahan dan tuntunan dalam penggunaan gadget (50\%); kadangkadang (33.4\%); dan 16.6\% mengatakan tidak. Sedangkan responden orang tua mengatakan mempunyai waktu dengan anak remaja (36\%); kadang-kadang (40\%); dan 24\% mengatakan tidak memberikan mempunyai waktu bersama anak remajanya. Selanjutnya, orang tua telah memberi arahan dan tuntunan dalam penggunaan gadget (60\%); kadang-kadang (28\%) dan 12\% mengatakan tidak memberikan arahan.

Dari hasil wawancara penulis kepada beberapa remaja mengatakan bahwa orang tua mempunyai waktu bersama, namun tidak setiap saat sehingga waktu yang berkualitas sangat rendah bersama mereka. ${ }^{23}$ Dan orang tua dari beberapa remaja mengatakan hal yang demikian bahwa kebersamaan dalam keluarga merupakan hal yang sangat penting, namun disadari bahwa waktu bersama untuk membicarakan tentang manfaat dan kegunaan teknologi masih belum maksimal disampaikan. ${ }^{24}$ Hasil penelitian menunjukkan bahwa:

Parents of 128 children in first through sixth grade consented to cognitive developmental assessment of their children and completed questionnaires on children's use of the Internet at home and family socioeconomic characteristics. In general, indices of home Internet use accounted for more of the variance in children's cognitive development than did indices of socioeconomic status. The ecological techno-subsystem furthers our understanding of

\footnotetext{
${ }^{21}$ Ibid.

${ }^{22}$ Wawancara Oleh Penulis kepada beberapa orang tua. Sentani, 25 Mei 2015.

${ }^{23}$ Wawancara Oleh Penulis kepada beberapa remaja. Sentani, 23 Mei 2015.

${ }^{24}$ Wawancara Oleh Penulis kepada beberapa orang tua. Sentani, 26 Mei 2015.
} 
environmental influences on child development by emphasizing the impact of digital technologies on cognitive growth during childhood. ${ }^{25}$

Berdasarkan hasil penelitian di atas bahwa penggunaan internet di rumah (keluarga) dapat memengaruhi perkembangan kognitif anakanak daripada menunjukkan status sosial-ekonomi. Pengaruh lingkungan terhadap perkembangan anak dipengaruhi oleh dampak teknologi digital pada perkembangan kognitif selama masa anak-anak. Dengan demikian, orang tua sebagai keluarga cyber smart yang aktif mendidik, mengarahkan anak-anaknya dan memiliki waktu bersama dalam penggunaan teknologi digital dapat memberikan dampak positif bagi perkembangan kognitif anak remaja dalam keluarganya.

\section{Diskusi}

Hasil pembahasan di atas memberikan beberapa hal untuk didiskusikan yaitu:

Pertama, apakah orang tua menyadari bahwa menjalankan pendidikan Kristen dalam keluarga merupakan tanggung jawab yang harus dilakukan dalam keluarga? Hasil penelitian menunjukkan bahwa belum optimalnya peran orang tua untuk terus-menerus mengajarkan pendidikan Kristen terutama dalam memahami dunia remaja yang sudah "bergaul" dengan teknologi digital.

Kedua, kendala bagi orang tua sekarang adalah perkembangan teknologi yang semakin pesat. Apakah orang tua sudah siap menjadi keluarga Cyber Smart yang cerdas untuk memahami tantangan globalisasi dengan lebih membuka diri terhadap perkembangan teknologi digital dan berperan serta dalam mendidik remaja dengan cara mereka menjalani kehidupan remajanya.

Ketiga, orang tua harus menyadari bahwa memberikan aturan/batasan kepada remaja sangatlah penting. Mediasi orang tua terhadap remaja sangat penting untuk menjalankan disiplin dengan pendekatan kasih Kristus supaya remaja tetap hormat kepada orang tuanya. Oleh karena itu, perlu untuk mengomukasikan semua aturan/batasan yang akan diberikan terlebih dahulu kepada remaja sebelum menjalankannya.

Keempat, orang tua sebagai Cyber Smart harus terlebih dahulu memberikan teladan kepada remaja dalam hal kerohanian dan dalam penggunaan gadget/internet. Sebab seorang pemimpin harus memberikan teladan kepada pengikutnya sebagaimana Yesus Kristus telah memberikan teladan kepada murid-murid-Nya.

\footnotetext{
${ }^{25}$ Genevieve Marie Johnson, "Internet Use and Child Development: Validation of the Ecological TechnoSubsystem," Educational Technology \& Society, 13/1, (2010): 176-185.
} 
Kelima, antara remaja dan orang tua harus terjalin hubungan yang baik agar dapat menciptakan komunikasi yang baik. Orang tua seharusnya menjadi tempat yang nyaman dan baik bagi remaja untuk berbagi informasi yang didapat dari dunia internet. Orang tua sebagai keluarga Cyber Smart mampu mengomunikasikan dengan baik setiap informasi dari internet dengan bijaksana dan berlandaskan norma-norma pendidikan Kristen.

\section{Kesimpulan}

Peran orang tua bagi remaja juga yaitu dengan menjadi seorang pendidik. Mendidik remaja dengan membicarakan, membahas dan menumbuh kembangkan nilai-nilai Kristen dalam diri remaja generasi ini berdasarkan firman Tuhan.

Orang tua sebagai keluarga Cyber Smart menyediakan waktu berkualitas dengan remaja di rumah atau di mana saja dan komunikasikanlah semua informasi yang didapat dari internet, orang tua juga menuntun anak remaja untuk memilih website yang mengandung unsur pendidikan, membantu anak remaja memilih nilai-nilai baik yang ditawarkan dari internet dan membimbing remaja untuk tetap menjadi garam dan terang di dunia maya.

Menyediakan banyak waktu di komputer tidak berdampak negatif kepada keterampilannya, namun sebaiknya internet dapat membantu menjaga komunikasi interpersonal dan mempertahankan hubungan sosial. Dampak penggunaan internet berlebihan pada anak-anak dan remaja dapat berakibat menjadi kesepian, berdampak pada hubungan sosial, dan kesejahteraan psikologisnya. ${ }^{26}$ Oleh karena itu, orang tua juga mempunyai peran untuk menjalankan disiplin bagi remaja. Disiplin berbicara mengenai banyak hal yang dapat dilakukan oleh orang tua kepada anak remaja yang berhubungan dengan alat komunikasi, media dan teknologi informasi yang digunakan. Dalam mengawasi dan memberikan aturan/batasan kepada remaja akan mengundang tanggapan yang kurang baik dari remaja. Namun, orang tua tetap harus melakukannya dengan kasih demi kebaikan anak remajanya.

Suasana di dalam keluarga sebagian besar tergantung pada cara orang tua membesarkan anak-anak mereka. Pada anak usia dini, anakanak benar-benar tergantung pada orang tua mereka karena mereka kebutuhan baik itu fisik, emosional, sosial maupun kognitif. Oleh karena

\footnotetext{
${ }^{26}$ Kaveri Subrahmanyama, Patricia Greenfield, Robert Kraut, Elisheva Gross, "The impact of computer use on children's and adolescents' development," Applied Developmental Psychology 22 (2001):26.
} 
itu, gaya mendidik anak-anak memiliki pengaruh pada anak-anak. ${ }^{27}$ Pengaruh peran orang tua dalam menjadi teladan yang baik dalam sebuah keluarga akan memengaruhi perilaku anak-anaknya. Remaja akan memerhatikan apa yang dilakukan dan mendengar apa yang akan diarahkan oleh orang tua.

Nikken mengemukakan bahwa "Orang tua menerapkan mediasi ketika mereka mengharapkan efek positif daripada dampak negatif dari internet. Oleh karena itu, orang tua sengaja menyesuaikan dengan kebutuhan dan kepentingan anak. ${ }^{28}$ Menjadi keluarga Cyber Smart adalah keluarga yang mampu memetik berbagai keuntungan dan manfaat dari kemajuan teknologi dan meminimalisasikan efek negatif yang mengikutinya. Sebagai orang tua, terbukalah terhadap perkembangan dan jadikanlah keluarga sebagai keluarga yang ramah akan teknologi dan tetap menjalankan prinsip-prinsip firman Tuhan.

\section{Kepustakaan}

Carlson, L., R. N. Laczniak and C. Wertley, "Parental Style." Journal of Advertising Research, 5l/2 (2011):427-435.

Chou, Mei-Ju, and Chiou-Fan Fen, "Parent-Child Play within Information Technology: A Quest for Quality Family Atmosphere," Procedia - Social and Behavioral Sciences 122, (2014 ):273 - 282.

Grace, Adewumi M., Olojo oludare Jethro, Falemu Funke Aina, "Roles Of Parent On The Academic Performance Of Pupils In Elementary Schools," International Journal of Academic Research in Business and Social Sciences 2, No. 1 (January, 2012): 196-201.

Griffith Institute for Educational Research, "The ACMA Cybersmart Outreach Program Evaluation Qualitative Report," diakses 10 Desember 2015, http://www.cybersmart.gov.au/About\%20Cyber smart/Research/ /media/Cybersmart/About\%20Cybersmart/Docum ents/The\%20ACMA\%20Cybersmart\%200utreach\%20Program $\% 20$ Evaluation\%20Qualitative\%20Report\%20October\%202011\%20Grif fith\%20University.PDF.

Grinnel, Ann. Pembacaan Wajib PAK Remaja-Pemuda. Makassar: STT Jaffray, 2012.

${ }^{27}$ Mei-Ju Chou, and Chiou-Fan Fen, "Parent-Child Play within Information Technology: A Quest for Quality Family Atmosphere," Procedia - Social and Behavioral Sciences 122, (2014 ):275; L. Carlson, R. N. Laczniak and C. Wertley, "Parental Style," Journal of Advertising Research, 5l/2 (2011):427-435.

${ }^{28}$ Peter Nikken, "Parental Mediation of Young Children's Internet Use," Mediation of Internet use, 2011,1, diakses 12 Januari 2016, http://www.lse.ac.uk/media@lse/ research/EUKidsOnline/Conference\%202011/Nikken.pdf. 
Howard Hendriks, Membina Temperamen Anda. Bandung: Kalam Hidup, 1982.

Johnson, Genevieve M. "Internet Use and Child Development: Validation of the Ecological TechnoSubsystem." Educational Technology \& Society, 13/1, (2010): 176-185.

Matheus, J. dan Elisabet Selfina, "Peran Pembina Remaja Bagi Perkembangan Perilaku Remaja Di GKII Tanjung Selor Kalimantan Utara." Jurnal Jaffray 13, No. 1 (April 2014): 1-22.

Nikken, Peter. "Parental Mediation of Young Children's Internet Use." Mediation of Internet use, 2011. Diakses 12 Januari 2016, http:// www.lse.ac.uk/media@lse/research/EUKidsOnline/Conference\%202 0ll/Nikken.pdf.

Pratama, Hellen Chou. Cyber Smart Parenting.Bandung: Visi Anugerah Indonesia, 2012.

"Suara Kenabian Tentang Anak dan Pemuda di Tengah Krisis." Buletin BPC Perkantas Edisi Agustus, 2009.

Subrahmanyama, K., Patricia Greenfield, Robert Kraut, Elisheva Gross, "The impact of computer use on children's and adolescents' development." Applied Developmental Psychology 22 (2001): 7-30.

Vasarhelyi, Miklos A. and Lynford Graham, "Cybersmart: The Future of Education in the Age of the Internet," diakses 10 Desember 2015, http://raw.rutgers.edu/MiklosVasarhelyi/Resume\%20Articles/PROF ESSIONAL\%20PAPERS/P17.\%20cybersmart\%20education\%20and $\% 20$ the $\% 20$ internet.pdf.

Wawancara

Ajamiseba, Anna. Wawancara Oleh Penulis. Sentani, 27 Mei 2015.

Cawem, Yosepina. Wawancara Oleh Penulis. Sentani, 21 Mei 2015.

Talahala, Yohana. Wawancara Oleh Penulis. Sentani, 23 Mei 2015.

Dorlince, Wawancara Oleh Penulis. Sentani, 21 Mei 2015. 